\title{
The capacity for adopting energy innovations in Portugal: Historical evidence and perspectives for the future
}

\author{
Nuno Bento ${ }^{\mathrm{a}, *}$, Margarida Fontes ${ }^{\mathrm{a}, \mathrm{b}}$ \\ a DINÂMIA'CET, ISCTE-IUL, Av. das Forças Armadas, Edificio ISCTE, Sala 2N19, 1649-026 Lisboa, Portugal \\ ${ }^{\text {b }}$ LNEG, Laboratório Nacional de Energia e Geologia, Estrada do Paço do Lumiar, 22, 1649-038 Lisboa, Portugal
}

\section{A R T I C L E I N F O}

Article history:

Received 14 May 2014

Received in revised form 14 July 2015

Accepted 1 September 2015

Available online $\mathrm{xxxx}$

\section{Keywords:}

Diffusion

Technological innovation systems

Up-scaling

Energy technologies

Portugal

\begin{abstract}
A B S T R A C T
This paper investigates the speed of adoption of energy technologies in a traditionally innovation importing country, Portugal, as compared with countries where these technologies first started. Data were collected on the growth of eight energy-related technologies, both energy supply (e.g. natural gas plants, wind turbines) and end-use (e.g., motorcycles). The analysis is done in terms of the evolution of the number of units and installed capacity, indicating possible scale effects. The results show an average adoption lag of one to two decades relatively to "Core" countries. However, the growth rate increases when a technology arrives at Portugal, confirming the hypothesis that adoption accelerates when technology reaches new markets. Additionally, the duration of diffusion in Portugal is less constrained by the final scale of diffusion, contrasting with previous observations for the Core. The data also uncover the successful diffusion of wind energy in Portugal, showing that growth took off less than a decade after the diffusion in the Core, and achieving similar levels of intensity. The analysis suggests that this was supported by the improvement in the adoption capacity, associated with the development of a wind energy innovation system. These findings open new perspectives for the spatial diffusion of sustainable innovations.
\end{abstract}

(c) 2015 Elsevier Inc. All rights reserved.

\section{Introduction}

The deployment of new energy technologies in large scale is needed in the next decades in order to overcome current societal challenges (e.g. environmental problems, security of supply) (IPCC, 2014). Historical experience reveals that the emergence and diffusion of energy technologies are slow and marked by a series of barriers (Grubler et al., 2012; Grubler, 2012; Fouquet, 2012). One of the reasons for this slowness is the extent of institutional and organizational changes that are often necessary for the emergence and dissemination of a new technology (Bergek et al., 2008; Jacobsson; Bergek, 2011). However, the analysis of international patterns of technology diffusion shows an acceleration of growth as the technology moves from pioneer countries and reaches new regions (Grubler, 2012, 1998; Bento, 2013). A possible explanation for this empirical regularity is the presence of externalities (i.e., "spillovers") from the technology development in pioneer countries, which supports its faster dissemination in subsequent markets (Jaffe, 2005; Perkins and Neumayer, 2005). The positioning of each country in the sequence of international diffusion depends on internal conditions, including the ability to absorb and use new technologies (Cohen and Levinthal, 1989, 1990).

\footnotetext{
* Corresponding author.

E-mail addresses: Nuno.Bento@iscte.pt (N. Bento), margarida.fontes@lneg.pt (M. Fontes)
}

The adoption of foreign technology is a key element in the convergence of the less developed economies with more advanced countries (Fagerberg and Godinho, 2008; Godinho, 1995). The notion of "latecomer advantage" has been put forward to explain the technological dynamism of less advanced countries over more developed ones (Gerschenkron, 1962). It is argued that the technological backwardness of the former allows them to absorb the most recent innovations developed in the latter, without having to bear the high initial costs of development (Perkins and Neumayer, 2005). In addition, they are not encumbered by the so-called vintage capital, which is known to be a factor that delays the transition to new technologies in pioneer countries, by creating stranded costs due to the previous investments in human capital and infrastructure (Unruh, 2000; Clark and Wrigley, 1997; Frankel, 1955). This line of reasoning can explain why the transition to new energy systems tends to take less time in follower countries, which benefit from both the experience gained from the diffusion in pioneer countries and a cheaper technology (Grubler, 2012). Wilson (2009) shows evidence of the acceleration of diffusion in late adopters for several energy supply and end-use technologies. The marketing and management literature also finds the same effect of faster diffusion in countries that adopt a given product innovation later, what has been called the "lead-lag effect" (see a review in Peres et al., 2010).

Portugal is an intermediate economy and a typical case of "follower" of technological changes initiated in the more advanced economies (Godinho, 2007; Godinho and Caraça, 1988). A few studies analyze the 